\title{
Health-related quality of life of patients with brain metastases selected for stereotactic radiosurgery
}

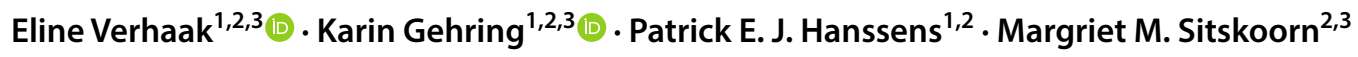

Received: 14 February 2019 / Accepted: 2 May 2019 / Published online: 9 May 2019

(c) The Author(s) 2019

\begin{abstract}
Purpose Information on health-related quality of life (HRQoL) of patients with brain metastases (BM) before stereotactic radiosurgery (SRS) is very relevant to improve communication between patients and clinicians and to be able to interpret changes in HRQoL after SRS. The aim of this study was to evaluate the prevalence and severity of complaints on different aspects of pre-SRS HRQoL among patients with BM and to identify predictors thereof.

Methods Patients with 1-10 newly diagnosed BM, expected survival $>3$ months, Karnofsky Performance Status $\geq 70$, and scheduled to undergo SRS were included. HRQoL was measured with the Functional Assessment of Cancer TherapyBrain (FACT-Br) questionnaire. One-sample z-tests were conducted to analyze differences between patients with BM and published normative data of a general adult sample and of an adult cancer sample. Multiple regression analyses were run to identify predictors of pre-SRS HRQoL.

Results On the individual level, most patients with BM (57.6\% of 92 included patients) reported complaints regarding emotional well-being. As a group, patients with BM reported significantly lower emotional well-being compared to both control groups and significantly higher social well-being compared to the general population. Worse psychological factors, e.g. physical fatigue, depression, mental fatigue and anxiety, predicted aspects of pre-SRS HRQoL.

Conclusions An increased understanding of pre-SRS HRQoL and predictors hereof, provides us with more insight into the well-being of our patients with BM and is necessary for the interpretation of (changes in) HRQoL after SRS.
\end{abstract}

Keywords Brain metastases $\cdot$ Cancer $\cdot$ Gamma knife radiosurgery $\cdot$ Health-related quality of life $\cdot$ Patient-reported outcome measures $\cdot$ Radiosurgery

\section{Introduction}

Often, patients with brain metastases (BM) experience several symptoms prior to treatment of the BM, such as headaches, seizures, focal neurological deficits and cognitive

Electronic supplementary material The online version of this article (https://doi.org/10.1007/s11060-019-03186-z) contains supplementary material, which is available to authorized users.

Karin Gehring

k.gehring@tilburguniversity.edu

1 Gamma Knife Center, Elisabeth-TweeSteden Hospital, Tilburg, The Netherlands

2 Department of Neurosurgery, Elisabeth-TweeSteden Hospital, Tilburg, The Netherlands

3 Department of Cognitive Neuropsychology, Tilburg University, Tilburg, The Netherlands deficits [1-4], which can negatively influence patients' health-related quality of life (HRQoL). Patients with BM rated HRQoL as the most important factor to be considered in choosing among available treatment options [5]. Since stereotactic radiosurgery (SRS) is increasingly used to treat patients with single or multiple BM [6, 7], evaluating HRQoL of patients selected for SRS has become more important.

Habets et al. [8] were the first to compare HRQoL of patients with BM selected for SRS to the general population. The pre-SRS HRQoL subscale scores of the 97 patients were significantly worse compared to the general population [8]. In a subsequent study, evaluating HRQoL in 55 patients with BM pre-SRS, $89 \%$ of the patients had a significantly worse score on at least 1 of the $6 \mathrm{HRQoL}$ scales compared to the general population, with physical functioning (57\%) most often affected [9]. 
Only a few studies investigated predictors of HRQoL in patients with BM. Higher KPS pre-SRS has been associated with better pre-SRS HRQoL [8] and post-SRS HRQoL [10, 11]. In addition, pre-SRS asymptomatic $\mathrm{BM}$, low recursive partitioning analysis (RPA) class, no seizures and no selfreported cognitive impairment were associated with higher HRQoL following SRS [11].

Information on pre-SRS HRQoL is crucial to the interpretation of (changes in) HRQoL after treatment, both for research and clinical practice. The aim of the current study is to evaluate the prevalence of patients with BM scoring clinically meaningful lower on different aspects of HRQoL pre-SRS as compared to the general adult population. In addition, the severity of HRQoL complaints were evaluated by comparing HRQoL scores of patients with BM to normative data of a general adult sample and of an adult cancer sample. The adult cancer sample was used to evaluate the additional effect of being diagnosed with BM. A second aim was to identify potential pre-SRS sociodemographic, clinical, psychological and cognitive predictors of pre-SRS HRQoL.

\section{Methods}

This study evaluates the pre-SRS data from a prospective single-arm study to evaluate cognitive functioning up to 21 months after SRS with Gamma Knife in patients with BM (CAR-Study A; ClinicalTrials.gov Identifier: NCT02953756). Secondary endpoints included patient reported outcomes. The study was approved by the medical ethics committee Brabant (File NL53472.028.15).

\section{Patients}

Patients with BM, scheduled for SRS, were screened in the Elisabeth-TweeSteden Hospital in Tilburg, The Netherlands. Eligibility criteria for SRS were: clinical presentation consistent with BM, contrast enhanced volumetric MRI-scan showing 1-10 newly diagnosed BM, histologically proven malignant primary tumor, lesion $\geq 3 \mathrm{~mm}$ from optic apparatus, Karnofsky Performance Status (KPS) $\geq 70$, and anticipated survival (independent of BM) $>3$ months. Exclusion criteria were: Small Cell Lung Cancer (SCLC), lymphoma, leukemia, leptomeningeal disease, contraindications for MRI or gadolinium contrast, and progressive symptomatic systemic disease without treatment options.

Additional eligibility criteria for study participation were: total tumor volume in the brain $\leq 30 \mathrm{~cm}^{3}$ (based on visual inspection of the MRI-scan) and age $\geq 18$ years. Additional exclusion criteria were: a second active primary tumor, presence of an active primary brain tumor, prior brain radiation, prior brain surgery, severe cerebrovascular disease in the past 2 years, additional (history of a) significant neurological or psychiatric condition, participation in a concurrent study with neuropsychological testing and/or HRQoL assessments, comorbid medical condition precluding adequate follow-up, lack of basic proficiency in Dutch, IQ below 85, severe aphasia, severe visual problems, and paralysis of the hand(s)/ $\operatorname{arm}(\mathrm{s})$.

\section{Procedure}

During the first SRS consultation and information visit, the radiation-oncologist screened for SRS and study eligibility and provided patients with information about the study and its procedures. Eligible patients were treated within 1 week after the first consultation visit. If patients were willing to participate in the study, a neuropsychological assessment (NPA), including questionnaires concerning HRQoL, fatigue, and anxiety and depression, was administered by a trained test-leader (neuropsychologist or neuropsychologist in training) on the morning prior to SRS. Completion of the NPA and questionnaires took approximately $60 \mathrm{~min}$. All patients signed for informed consent.

\section{Measures}

HRQoL was measured with the Functional Assessment of Cancer Therapy-Brain (FACT-Br) [12]. The FACT-Br is a commonly used instrument to measure general HRQoL and specific symptoms or problems associated with brain tumors across five subscales, two total scores, and one index score (Table 1). Higher scores indicate a better HRQoL [12-15]. Published data from two normative samples provided by Brucker et al. [16] were used to compare pretreatment HRQoL of the patients with BM to. The first normative sample consisted of 1075 persons from the general U.S. adult population (age range $=18-91,51 \%$ female). The second normative sample consisted of 2236 adult cancer patients (age range $=18-92,57 \%$ female).

In addition, symptoms of anxiety and depression were measured with the Hospital Anxiety and Depression Scale (HADS) [17] and fatigue was measured with the Multidimensional Fatigue Inventory (MFI) [18] (Table 1).

For the current analyses, the cognitive factors immediate and delayed verbal memory (Hopkins Verbal Learning Test-Revised [19]), executive functioning (Trail Making Test [20]; the performance on part B given the performance on part A), and dominant and non-dominant motor dexterity (Grooved Pegboard [21]) were selected as (possible) cognitive predictors for HRQoL. Previous studies demonstrated that performances on these domains were most frequently impaired in patients with $\mathrm{BM}[4,8,22]$. Raw cognitive test scores were converted into Z-scores based on our own normative group consisting of 104 
Table 1 Patient reported outcome measures

\begin{tabular}{|c|c|c|}
\hline Questionnaires & Description & Scales/items \\
\hline $\begin{array}{l}\text { Functional Assessment of Cancer Therapy-Brain } \\
\text { (FACT-Br) }\end{array}$ & $\begin{array}{l}\text { The FACT-Br was developed for patients with } \\
\text { primary brain tumors. Questions are answered } \\
\text { on a 5-point Likert scale ranging from } 0 \text { (not } \\
\text { at all) to } 4 \text { (very much), based on the past } \\
7 \text { days. Higher scores indicate a better HRQoL. } \\
\text { The } 5 \text { subscales of the FACT-Br are focused } \\
\text { on physical, social, emotional, and functional } \\
\text { well-being, and additional concerns of patients } \\
\text { with brain tumors. The FACT-General total } \\
\text { score measures overall HRQoL and can be } \\
\text { used in various groups of patients with cancer. } \\
\text { In the FACT-Br total scale, a disease-specific } \\
\text { subscale (i.e., additional concerns) is added to } \\
\text { the FACT-General to measure HRQoL concerns } \\
\text { specific to patients with a brain tumor. The trial } \\
\text { outcome index combines physical well-being, } \\
\text { functional well-being and the brain cancer sub- } \\
\text { scale [12-15]. The FACT-Br has good internal } \\
\text { consistency (.69 to .84) and reliability coef- } \\
\text { ficients (.60 to .83) [14] and has been proven to } \\
\text { be a valid HRQoL measure for use in patients } \\
\text { with BM [13] }\end{array}$ & $\begin{array}{l}\text { - Five subscales } \\
\text { - Physical well-being } \\
\text { - Social/family well-being } \\
\text { - Emotional well-being } \\
\text { - Functional well-being } \\
\text { - Brain cancer subscale (additional } \\
\text { concerns specific for patients with } \\
\text { brain tumors) } \\
\text { - Two total scales } \\
\text { - FACT-General (FACT-G; physi- } \\
\text { cal+ social+emotional + functional } \\
\text { well-being) } \\
\text { - FACT-Brain (FACT-Br; FACT- } \\
\text { G+ brain cancer subscale) } \\
\text { - One index } \\
\text { - Trial Outcome Index (TOI; physi- } \\
\text { cal + functional well-being + brain } \\
\text { cancer subscale) }\end{array}$ \\
\hline Hospital Anxiety and Depression Scale (HADS) & $\begin{array}{l}\text { The HADS is a brief } 14 \text {-item self-report measure } \\
\text { consisting of seven anxiety items and seven } \\
\text { depression items, measured on 4-point response } \\
\text { scales (ranging from } 0 \text { to } 3 \text { ), referring to overt } \\
\text { symptoms within the preceding week. Two } \\
\text { subscales, anxiety and depression, can be calcu- } \\
\text { lated. A score } \geq 8 \text { on each subscale is an indica- } \\
\text { tion for mild anxiety or depression }[17,33]\end{array}$ & $\begin{array}{l}\text { - Anxiety } \\
\text { - Depression }\end{array}$ \\
\hline Multidimensional Fatigue Inventory (MFI) & $\begin{array}{l}\text { The MFI is a self-report instrument and consists } \\
\text { of } 20 \text { items grouped in five dimensions each } \\
\text { containing four items. The responder indicates } \\
\text { on a five-point scale to what extent the state- } \\
\text { ment applies to him or her based on the last } \\
\text { couple of days. A higher score indicates more } \\
\text { fatigue }[18,34]\end{array}$ & $\begin{array}{l}\text { - General fatigue } \\
\text { - Physical fatigue } \\
\text { - Reduced activity } \\
\text { - Reduced motivation } \\
\text { - Mental fatigue }\end{array}$ \\
\hline
\end{tabular}

$B M$ brain metastases, FACT-Br Functional Assessment of Cancer Therapy-Brain, FACT-G FACT-General, HADS Hospital Anxiety and Depression Scale, HRQoL Health-Related Quality of Life, MFI Multidimensional Fatigue Inventory, TOI Trial Outcome Index

Dutch non-cancer adults (see Online Resource 1 for a comparison of the characteristics of our patient sample and the non-cancer controls). Individual $Z$-scores were calculated using the following formula: $\mathrm{Z}$-score $=\mathrm{Y}_{\mathrm{o}}-\mathrm{Y}_{\mathrm{p}}$ ' $\mathrm{SD}_{\text {residual }}$, where $\mathrm{Y}_{\mathrm{o}}$ is the raw cognitive test score of the individual, $\mathrm{Y}_{\mathrm{p}}$ is the predicted raw cognitive test score using normative regression-based formulae (including age, sex and education as covariates resulting in sociodemographic adjusted norms), and $\mathrm{SD}_{\text {residual }}$ is the $\mathrm{SD}$ of the general population's residual (see for example Rijnen et al. [23]).

Socio-demographic and clinical factors were retrieved from patient's medical files (Table 2).

\section{Statistical analyses}

Individual raw HRQoL scores of the patients with BM were converted to $\mathrm{T}$-scores $(\mathrm{M}=50$, standard deviation $(\mathrm{SD})=10)$, using the conversion tables based on data from the general U.S. adult population as provided by Brucker et al. [16]. A T-score of half a SD below the normative mean (T-score $\leq 45$ ) was defined as clinically meaningful lower as compared to the general population [16]. The number of patients with a $T$-score $\leq 45$ were counted to determine the prevalence of patients who scored clinically meaningful lower as compared to the general population. 
Table 2 Patient characteristics

\begin{tabular}{|c|c|}
\hline & No. of patients $(\%)$ \\
\hline Number of patients & 92 \\
\hline Age in years, median (range) & $63(31-80)$ \\
\hline Sex, male & $47(51.1)$ \\
\hline \multicolumn{2}{|l|}{ Education $^{\mathrm{a}}$} \\
\hline Low & $28(30.4)$ \\
\hline Middle & $37(40.2)$ \\
\hline High & $27(29.3)$ \\
\hline \multicolumn{2}{|l|}{ Histology of the primary cancer } \\
\hline Lung (NSCLC) & $55(59.8)$ \\
\hline Renal & $15(16.3)$ \\
\hline Melanoma & $12(13.0)$ \\
\hline Breast & $6(6.5)$ \\
\hline Other & $4(4.4)$ \\
\hline \multicolumn{2}{|l|}{ Number of BM } \\
\hline 1 & $32(34.8)$ \\
\hline $2-4$ & $29(31.5)$ \\
\hline $5-10$ & $31(33.7)$ \\
\hline Total tumor volume $\mathrm{cm}^{3}$, median (range) & $5.6(0.02-31.1)$ \\
\hline KPS, median (range) & $90(70-100)$ \\
\hline \multicolumn{2}{|l|}{ RPA } \\
\hline Class 1 & $16(17.4)$ \\
\hline Class 2 & $76(82.6)$ \\
\hline \multicolumn{2}{|l|}{ GPA } \\
\hline Class 2 & $15(16.3)$ \\
\hline Class 3 & $60(65.2)$ \\
\hline Class 4 & $17(18.5)$ \\
\hline \multicolumn{2}{|l|}{ Seizures } \\
\hline Yes & $22(23.9)$ \\
\hline No & $70(76.1)$ \\
\hline \multicolumn{2}{|l|}{ Diagnosis of BM } \\
\hline Synchronous & $28(30.4)$ \\
\hline Metachronous & $64(69.6)$ \\
\hline \multicolumn{2}{|l|}{ Symptomatic BM } \\
\hline Symptomatic & $64(69.6)$ \\
\hline Asymptomatic & $28(30.4)$ \\
\hline \multicolumn{2}{|l|}{ Symptoms of anxiety ${ }^{b}$} \\
\hline No indication for anxiety & $53(57.6)$ \\
\hline Indication for mild anxiety & $39(42.4)$ \\
\hline \multicolumn{2}{|l|}{ Symptoms of depression ${ }^{\mathrm{b}}$} \\
\hline No indication for depression & $62(67.4)$ \\
\hline Indication for mild depression & $30(32.6)$ \\
\hline
\end{tabular}

$B M$ brain metastases, GPA graded prognostic assessment, KPS Karnofsky performance status, No. number, NSCLC non-small cell lung cancer, $R P A$ recursive partitioning analysis

${ }^{a}$ The seven categories to classify the level of education of the Verhage scale [35] were merged into low (Verhage 1-4), middle (Verhage 5), and high (Verhage 6 and 7) educational level

${ }^{\mathrm{b}} \mathrm{A}$ score $\geq 8$ per subscale is an indication for mild anxiety/depression [17]
One-sample $z$ tests were conducted to investigate if there were statistical differences in mean HRQoL T-scores between patients with $\mathrm{BM}$ and the sample from the general population $(\mathrm{T}$-score $=50, \mathrm{SD}=10)$ and between patients with $\mathrm{BM}$ and the adult cancer sample (again, $\mathrm{T}$-score $=50$, $\mathrm{SD}=10$ ) for all HRQoL subscales. As a measure of effect size, Glass' Delta was calculated, by dividing the difference between the means of the groups by the standard deviation of the normative group for each FACT-Br subscale. An effect size $\leq 0.49$ was considered a 'small' effect, from 0.50 to 0.79 a 'medium' effect and $\geq 0.80$ a 'large' effect [24].

Meaningful differences, based on clinical and subjective indicators, were provided by Brucker et al. [16] as well. A mean difference of $\geq 2$ points for the subscales physical, social, emotional and functional well-being and a mean difference of $\geq 5$ points for general HRQoL were considered clinically meaningful.

Exploratory univariate linear regression analyses were performed in order to select candidate variables for use in the final multiple regression models. The univariate regression analyses included pretreatment socio-demographic (sex and age), clinical (KPS, RPA class, GPA class, total BM volume $\left(\mathrm{cm}^{3}\right)$, (previous) seizures, symptomatic BM, illness duration (time in months between diagnosis of the primary cancer and SRS) and, synchronous versus metachronous diagnosis of BM (within or after 30 days of the diagnosis of the primary tumor, respectively), psychological (fatigue, depression and anxiety), and cognitive factors (immediate and delayed verbal memory, executive functioning and motor dexterity). For each factor and HRQoL subscale a separate regression analysis was run.

In a second step, the multiple regression analyses were run, for each HRQoL scale, in which all statistically significant factors $(p<.05)$ of the initial linear regression analyses were included, resulting in eight regression models. If the assumption of homoscedasticity was violated, weighted least-squares (WLS) regressions were conducted. The absolute residuals were used as dependent variable in the multiple regression analyses to estimate the conditional error variances. Conditional error variances are used to calculate the weight variable, using the following formula: weight $=1 /$ (conditional error variances ${ }^{2}$ ).

Statistical analyses were performed with SPSS version 24 (IBM Corp, 2016). A corrected alpha, based on the procedure of Benjamini-Hochberg [25], was used to reduce the false discovery rate due to multiple testing, separately for the one-samples z-tests, for the 8 multiple regression models and for the overall regression models. 


\section{Results}

Ninety-two patients with BM were included (Table 2). The median age of the patients was 63 years (range 31-80). Most frequent were a solitary BM (34.8\%), primary NonSmall Cell Lung Cancer (NSCLC; 59.8\%), and GPA class $3(65.2 \%)$. The median total tumor volume in the brain was $5.6 \mathrm{~cm}^{3}$.

\section{Health-related quality of life}

On the individual level, $64.1 \%$ of the patients had clinically meaningful low HRQoL (T-score $\leq 45$ ) on at least one aspect of HRQoL as compared to the general adult population. The highest frequencies of low HRQoL scores were found for emotional well-being $(57.6 \%)$, functional wellbeing (35.9\%) and general HRQoL (32.6\%) (Table 3).

At the level of group means, patients with BM, as compared to the general population [16], had a significantly and clinically meaningful (e.g. $>2$ points difference) better social well-being and worse emotional well-being (Table 3). Compared to the adult cancer sample [16], patients with BM had significantly and clinically meaningful lower mean scores on emotional well-being (Table 3). Although there was no statistically significant difference on physical wellbeing between patients with BM and the adult cancer sample, patients with BM reported a clinically meaningful better physical well-being compared to the adult cancer sample.

\section{Predictors of baseline health-related quality of life}

Results of the exploratory univariate analyses are presented in the supplementary Online Resource 2. Factors selected for subsequent multiple regression analyses are presented in Table 4. Due to multicollinearity between the subscales of the MFI, general fatigue and reduced activity were excluded (each had a high correlation with physical fatigue, $\mathrm{r}=.866$ and $\mathrm{r}=.736$, respectively).

All regression models significantly predicted HRQoL $(p \leq .001)$ (Table 4). Better physical well-being was associated with lower levels of physical and mental fatigue. Better

Table 3 Percentages of patients with BM with low HRQoL and mean HRQoL scores of patients with BM compared to normative data of the general adult population and adult cancer sample

\begin{tabular}{|c|c|c|c|c|c|c|c|c|c|}
\hline \multirow[t]{2}{*}{$\begin{array}{l}\text { Normative data of the } \\
\text { general population }\end{array}$} & \multirow{2}{*}{$\begin{array}{l}\text { Percentage of patients scoring clini- } \\
\text { cally meaningful lower compared } \\
\text { to the general adult population }(\%)\end{array}$} & \multicolumn{4}{|c|}{ Patients with BM $(n=92)$} & \multicolumn{4}{|c|}{$\begin{array}{l}\text { Patients with } B M \text { versus general } \\
\text { population }(n=1075)^{\mathrm{a}}\end{array}$} \\
\hline & & Mean raw score & SD & Mean T-score & $\mathrm{SD}$ & Mean diff & $\mathrm{z}$ & $p^{\mathrm{b}}$ & Effect size $^{\mathrm{c}}$ \\
\hline Physical well-being & 27.2 & 22.7 & 4.8 & 50.0 & 8.9 & 0.0 & 0.0 & 1.00 & .00 \\
\hline Social well-being & 7.6 & 23.0 & 5.3 & 55.6 & 7.8 & 5.6 & 5.4 & $<.001$ & .56 \\
\hline Emotional well-being & 57.6 & 16.0 & 4.7 & 41.9 & 9.8 & -8.1 & -7.8 & $<.001$ & .81 \\
\hline Functional well-being & 35.9 & 17.9 & 6.1 & 49.1 & 8.9 & -0.9 & -0.9 & .39 & .09 \\
\hline FACT-General & 32.6 & 79.6 & 15.6 & 49.7 & 8.6 & -0.3 & -0.3 & .77 & .03 \\
\hline Additional concerns $^{\mathrm{d}}$ & & 50.5 & 11.2 & & & & & & \\
\hline FACT-Brain $^{\mathrm{d}}$ & & 130.1 & 24.0 & & & & & & \\
\hline Trial outcome index ${ }^{\mathrm{d}}$ & & 91.1 & 18.8 & & & & & & \\
\hline
\end{tabular}

\begin{tabular}{|c|c|c|c|c|c|c|}
\hline \multirow{2}{*}{$\begin{array}{l}\text { Normative data of adult cancer } \\
\text { sample }^{\mathrm{e}}\end{array}$} & \multicolumn{2}{|c|}{ Patients with BM $(n=92)$} & \multicolumn{4}{|c|}{ Patients with BM versus adult cancer sample $(n=2236)^{\mathrm{e}}$} \\
\hline & Mean T-score & $\mathrm{SD}$ & Mean diff & $\mathrm{z}$ & $p^{\mathrm{b}}$ & Effect size $^{\mathrm{c}}$ \\
\hline Physical well-being & 52.3 & 8.0 & 2.3 & 2.2 & .03 & .23 \\
\hline Social well-being & 51.5 & 10.0 & 1.5 & 1.4 & .15 & .15 \\
\hline Emotional well-being & 44.0 & 10.4 & -6.0 & -5.8 & $<.001$ & .60 \\
\hline Functional well-being & 48.5 & 8.9 & -1.5 & -1.4 & .15 & .15 \\
\hline FACT-general & 49.2 & 9.2 & -0.8 & -0.8 & .44 & .08 \\
\hline
\end{tabular}

Bold text indicates a statistically significant difference

$B M$ brain metastases, FACT Functional assessment of cancer therapy, HRQoL health-related quality of life, mean diff mean difference, $n$ number of participants, $S D$ standard deviation

${ }^{a}$ Normative data of general population $(n=1075)$ of Brucker et al. [16], mean 50; SD 10

${ }^{\mathrm{b}}$ Corrected alpha of .015, using the Benjamini-Hochberg procedure [25]

${ }^{\mathrm{c}}$ Glass's Delta

${ }^{\mathrm{d}}$ Normative data not available

${ }^{\mathrm{e}}$ Normative data of adult cancer sample $(\mathrm{n}=2236)$ of Brucker et al. [16], mean 50; SD 10 
Table 4 Multivariate analyses of predictors of pre-SRS HRQoL

\begin{tabular}{|c|c|c|c|c|c|}
\hline & & $\mathrm{PWB}^{\mathrm{a}}$ & $\mathrm{SWB}^{\mathrm{a}}$ & EWB & FWB \\
\hline \multicolumn{6}{|l|}{ Model summary } \\
\hline $\mathrm{F}$ & & 26.775 & 24.903 & 25.955 & 19.268 \\
\hline Adjusted $R^{2}$ & & .723 & .570 & .526 & .552 \\
\hline$p$ value* & & $<.001$ & $<.001$ & $<.001$ & $<.001$ \\
\hline $\mathrm{n}$ & & 90 & 91 & 91 & 90 \\
\hline \multicolumn{6}{|l|}{ Clinical factors } \\
\hline $\begin{array}{l}\text { KPS } \\
70-80 \text { versus } 90-100 \text { (ref) }\end{array}$ & $\begin{array}{l}\mathrm{b} \\
95 \% \mathrm{CI} \\
p \text { value }^{*}\end{array}$ & $\begin{array}{l}-0.077 \\
-1.093 \text { to } 0.939 \\
.881\end{array}$ & NS & NS & $\begin{array}{l}-0.290 \\
-2.372 \text { to } 1.791 \\
.782\end{array}$ \\
\hline $\begin{array}{l}\text { Seizures } \\
\text { Yes versus No (ref) }\end{array}$ & $\begin{array}{l}\mathrm{b} \\
95 \% \mathrm{CI} \\
p \text { value }^{*}\end{array}$ & NS & $\begin{array}{l}-1.848 \\
-4.734 \text { to } 1.038 \\
.206\end{array}$ & NS & NS \\
\hline $\begin{array}{l}\text { RPA } \\
\text { Class } 1 \text { versus Class } 2 \text { (ref) }\end{array}$ & $\begin{array}{l}\mathrm{b} \\
95 \% \mathrm{CI} \\
p \text { value }^{*}\end{array}$ & $\begin{array}{l}-1.269 \\
-3.676 \text { to } 1.139 \\
.297\end{array}$ & NS & NS & NS \\
\hline Illness duration & $\begin{array}{l}\mathrm{b} \\
95 \% \mathrm{CI} \\
p \text { value }^{*}\end{array}$ & $\begin{array}{l}-0.016 \\
-0.034 \text { to } 0.002 \\
.088\end{array}$ & NS & NS & NS \\
\hline $\begin{array}{l}\text { Diagnosis of BM } \\
\text { Metachronous versus synchronous (ref) }\end{array}$ & $\begin{array}{l}\mathrm{b} \\
95 \% \mathrm{CI} \\
p \text { value }^{*}\end{array}$ & $\begin{array}{l}-0.604 \\
-1.676 \text { to } 0.469 \\
.266\end{array}$ & $\begin{array}{l}-2.863 \\
-4.554 \text { to }-1.173 \\
\mathbf{. 0 0 1}\end{array}$ & NS & NS \\
\hline \multicolumn{6}{|l|}{ Psychological factors } \\
\hline Physical fatigue & $\begin{array}{l}\mathrm{b} \\
95 \% \mathrm{CI} \\
p \text { value }^{*}\end{array}$ & $\begin{array}{l}-0.409 \\
-0.543 \text { to }-0.275 \\
<.001\end{array}$ & NS & $\begin{array}{l}-0.087 \\
-0.279 \text { to } 0.105 \\
.372\end{array}$ & $\begin{array}{l}-0.446 \\
-0.699 \text { to }-0.192 \\
\mathbf{. 0 0 1}\end{array}$ \\
\hline Reduced motivation & $\begin{array}{l}\mathrm{b} \\
95 \% \mathrm{CI} \\
p \text { value }^{*}\end{array}$ & $\begin{array}{l}-0.020 \\
-0.170 \text { to } 0.131 \\
.796\end{array}$ & $\begin{array}{l}0.251 \\
0.183 \text { to } 0.319 \\
<.001\end{array}$ & $\begin{array}{l}-0.197 \\
-0.448 \text { to } 0.053 \\
.121\end{array}$ & $\begin{array}{l}-0.282 \\
-0.594 \text { to } 0.031 \\
.077\end{array}$ \\
\hline Mental fatigue & $\begin{array}{l}\mathrm{b} \\
95 \% \mathrm{CI} \\
p \text { value }^{*}\end{array}$ & $\begin{array}{l}-0.175 \\
-0.290 \text { to }-0.061 \\
\mathbf{. 0 0 3}\end{array}$ & NS & NS & $\begin{array}{l}0.081 \\
-0.158 \text { to } 0.320 \\
.500\end{array}$ \\
\hline Anxiety & $\begin{array}{l}\mathrm{b} \\
95 \% \mathrm{CI} \\
p \text { value }^{*}\end{array}$ & $\begin{array}{l}-0.074 \\
-0.223 \text { to } 0.075 \\
.324\end{array}$ & NS & $\begin{array}{l}-0.629 \\
-0.834 \text { to }-0.425 \\
<.001\end{array}$ & $\begin{array}{l}-0.004 \\
-0.270 \text { to } 0.262 \\
.975\end{array}$ \\
\hline Depression & $\begin{array}{l}\mathrm{b} \\
95 \% \mathrm{CI} \\
p \text { value }^{*}\end{array}$ & $\begin{array}{l}-0.223 \\
-0.418 \text { to }-0.028 \\
.025\end{array}$ & $\begin{array}{l}-0.289 \\
-0.507 \text { to }-0.072 \\
\mathbf{. 0 1 0}\end{array}$ & $\begin{array}{l}-0.080 \\
-0.320 \text { to } 0.160 \\
.510\end{array}$ & $\begin{array}{l}-0.645 \\
-0.970 \text { to }-0.320 \\
<.001\end{array}$ \\
\hline \multicolumn{6}{|l|}{ Cognitive factors } \\
\hline Immediate verbal memory & $\begin{array}{l}\mathrm{b} \\
95 \% \mathrm{CI} \\
p \text { value }^{*}\end{array}$ & NS & $\begin{array}{l}0.003 \\
-0.470 \text { to } 0.476 \\
.990\end{array}$ & NS & NS \\
\hline $\begin{array}{l}\text { Motor dexterity } \\
\text { Dominant hand }\end{array}$ & $\begin{array}{l}\mathrm{b} \\
95 \% \mathrm{CI} \\
p \text { value }^{*}\end{array}$ & NS & NS & NS & NS \\
\hline $\begin{array}{l}\text { Motor dexterity } \\
\text { Non- dominant hand }\end{array}$ & $\begin{array}{l}\mathrm{b} \\
95 \% \mathrm{CI} \\
p \text { value* }\end{array}$ & NS & NS & NS & NS \\
\hline
\end{tabular}


Table 4 (continued)

\begin{tabular}{|c|c|c|c|c|c|}
\hline & & FACT-G & BRCS & FACT-Br & TOI \\
\hline \multicolumn{6}{|l|}{ Model summary } \\
\hline $\mathrm{F}$ & & 22.066 & 9.353 & 20.990 & 21.351 \\
\hline Adjusted $R^{2}$ & & .624 & .475 & .684 & .688 \\
\hline$p$ value* & & $<.001$ & $<.001$ & $<.001$ & $<.001$ \\
\hline $\mathrm{n}$ & & 90 & 84 & 84 & 84 \\
\hline \multicolumn{6}{|l|}{ Clinical factors } \\
\hline $\begin{array}{l}\text { KPS } \\
70-80 \text { versus } 90-100 \text { (ref) }\end{array}$ & $\begin{array}{l}\mathrm{b} \\
95 \% \mathrm{CI} \\
p \text { value }^{*}\end{array}$ & $\begin{array}{l}0.707 \\
-4.288 \text { to } 5.702 \\
.779\end{array}$ & $\begin{array}{l}-1.969 \\
-6.914 \text { to } 2.975 \\
.430\end{array}$ & $\begin{array}{l}-1.613 \\
-9.619 \text { to } 6.394 \\
.689\end{array}$ & $\begin{array}{l}-1.800 \\
-8.070 \text { to } 4.470 \\
.569\end{array}$ \\
\hline $\begin{array}{l}\text { Seizures } \\
\text { Yes versus No (ref) }\end{array}$ & $\begin{array}{l}\mathrm{b} \\
95 \% \mathrm{CI} \\
p \text { value }^{*}\end{array}$ & NS & NS & NS & NS \\
\hline $\begin{array}{l}\text { RPA } \\
\text { Class } 1 \text { versus Class } 2 \text { (ref) }\end{array}$ & $\begin{array}{l}\mathrm{b} \\
95 \% \mathrm{CI} \\
p \text { value }^{*}\end{array}$ & NS & NS & NS & NS \\
\hline Illness duration & $\begin{array}{l}\mathrm{b} \\
95 \% \mathrm{CI} \\
p \text { value }^{*}\end{array}$ & NS & NS & NS & NS \\
\hline $\begin{array}{l}\text { Diagnosis of BM } \\
\text { Metachronous versus synchronous (ref) }\end{array}$ & $\begin{array}{l}\mathrm{b} \\
95 \% \mathrm{CI} \\
p \text { value }^{*}\end{array}$ & $\begin{array}{l}-3.931 \\
-8.649 \text { to } 0.788 \\
.101\end{array}$ & $\begin{array}{l}-1.169 \\
-5.565 \text { to } 3.227 \\
.598\end{array}$ & $\begin{array}{l}-6.640 \\
-13.758 \text { to } 0.479 \\
.067\end{array}$ & $\begin{array}{l}-3.257 \\
-8.831 \text { to } 2.317 \\
.248\end{array}$ \\
\hline \multicolumn{6}{|l|}{ Psychological factors } \\
\hline Physical fatigue & $\begin{array}{l}\mathrm{b} \\
95 \% \mathrm{CI} \\
p \text { value }^{*}\end{array}$ & $\begin{array}{l}-1.054 \\
-1.646 \text { to }-0.461 \\
\mathbf{. 0 0 1}\end{array}$ & $\begin{array}{l}-0.490 \\
-1.078 \text { to } 0.097 \\
.101\end{array}$ & $\begin{array}{l}-1.272 \\
-2.224 \text { to }-0.321 \\
.009\end{array}$ & $\begin{array}{l}-1.303 \\
-2.048 \text { to }-0.558 \\
\mathbf{. 0 0 1}\end{array}$ \\
\hline Reduced motivation & $\begin{array}{l}\mathrm{b} \\
95 \% \mathrm{CI} \\
p \text { value }^{*}\end{array}$ & $\begin{array}{l}-0.765 \\
-1.495 \text { to }-0.035 \\
.040\end{array}$ & $\begin{array}{l}-0.025 \\
-0.730 \text { to } 0.679 \\
.943\end{array}$ & $\begin{array}{l}-1.067 \\
-2.208 \text { to } 0.074 \\
.066\end{array}$ & $\begin{array}{l}-0.383 \\
-1.276 \text { to } 0.511 \\
.396\end{array}$ \\
\hline Mental fatigue & $\begin{array}{l}\mathrm{b} \\
95 \% \mathrm{CI} \\
p \text { value }^{*}\end{array}$ & $\begin{array}{l}0.314 \\
-0.264 \text { to } 0.892 \\
.283\end{array}$ & $\begin{array}{l}-0.733 \\
-1.303 \text { to }-0.163 \\
.012\end{array}$ & $\begin{array}{l}-0.077 \\
-1.000 \text { to } 0.846 \\
.869\end{array}$ & $\begin{array}{l}-0.597 \\
-1.320 \text { to } 0.125 \\
.104\end{array}$ \\
\hline Anxiety & $\begin{array}{l}\mathrm{b} \\
95 \% \mathrm{CI} \\
p \text { value }^{*}\end{array}$ & $\begin{array}{l}-0.725 \\
-1.354 \text { to }-0.097 \\
.024\end{array}$ & $\begin{array}{l}-0.043 \\
-0.662 \text { to } 0.577 \\
.892\end{array}$ & $\begin{array}{l}-0.854 \\
-1.858 \text { to } 0.149 \\
.094\end{array}$ & $\begin{array}{l}-0.061 \\
-0.847 \text { to } 0.725 \\
.878\end{array}$ \\
\hline Depression & $\begin{array}{l}\mathrm{b} \\
95 \% \mathrm{CI} \\
p \text { value }^{*}\end{array}$ & $\begin{array}{l}-1.356 \\
-2.117 \text { to }-0.596 \\
\mathbf{. 0 0 1}\end{array}$ & $\begin{array}{l}-0.938 \\
-1.678 \text { to }-0.197 \\
.014\end{array}$ & $\begin{array}{l}-2.526 \\
-3.725 \text { to }-1.327 \\
<.001\end{array}$ & $\begin{array}{l}-2.238 \\
-3.177 \text { to }-1.299 \\
<.001\end{array}$ \\
\hline \multicolumn{6}{|l|}{ Cognitive factors } \\
\hline Immediate verbal memory & $\begin{array}{l}\mathrm{b} \\
95 \% \mathrm{CI} \\
p \text { value }^{*}\end{array}$ & NS & NS & NS & NS \\
\hline $\begin{array}{l}\text { Motor dexterity } \\
\text { Dominant hand }\end{array}$ & $\begin{array}{l}\mathrm{b} \\
95 \% \mathrm{CI} \\
p \text { value }^{*}\end{array}$ & NS & $\begin{array}{l}0.705 \\
-0.004 \text { to } 1.415 \\
.051\end{array}$ & $\begin{array}{l}1.265 \\
0.116 \text { to } 2.414 \\
.031\end{array}$ & $\begin{array}{l}0.795 \\
-0.105 \text { to } 1.694 \\
.083\end{array}$ \\
\hline $\begin{array}{l}\text { Motor dexterity } \\
\text { Non-dominant hand }\end{array}$ & $\begin{array}{l}\mathrm{b} \\
95 \% \mathrm{CI} \\
p \text { value }^{*}\end{array}$ & NS & $\begin{array}{l}0.145 \\
-0.836 \text { to } 1.126 \\
.769\end{array}$ & $\begin{array}{l}-0.029 \\
-1.618 \text { to } 1.560 \\
.971\end{array}$ & $\begin{array}{l}0.022 \\
-1.222 \text { to } 1.266 \\
.972\end{array}$ \\
\hline
\end{tabular}


Table 4 (continued)

Bold text indicates a statistically significant result

$B R C S$ brain cancer subscale, $C I$ confidence interval, $E W B$ emotional well-being, $F A C T$ - $B r$ functional assessment of cancer therapy-Brain, $F A C T$ - $G$ FACT-General, $F W B$ functional well-being, $H R Q o L$ health-related quality of life, KPS Karnofsky performance status, $n$ number of patients, $N S$ not selected based on univariate analyses $(p \geq .05), P W B$ physical well-being, ref: reference category, $R P A$ recursive partitioning analysis, $S W B$ social well-being, TOI trial outcome index

*Corrected alpha's, following the Benjamini-Hochberg procedure [25], were .05 for the overall models, .011 for PWB, .01 for SWB, .008 for EWB, .017 for FWB, .014 for FACT-G, .006 for BRCS, and .011 for FACT-Br and TOI. Not selected factors: sex, age, GPA class, total BM volume $\left(\mathrm{cm}^{3}\right)$, symptomatic BM, delayed verbal memory, and executive functioning

${ }^{\mathrm{a}}$ Weighted least squares regression

social well-being was associated with a synchronous diagnosis of BM, lower levels of reduced motivation, and fewer symptoms of depression. Better emotional well-being was associated with fewer symptoms of anxiety. Better functional well-being and general HRQoL were associated with lower levels of physical fatigue and fewer symptoms of depression. Better FACT-Brain and trial outcome index scores were associated with lower levels of physical fatigue and fewer symptoms of depression. None of the factors added significantly to the prediction of additional concerns.

\section{Discussion}

On the individual level, $64.1 \%$ of the patients with BM already reported clinically meaningful low HRQoL on at least one subscale just before treatment, compared to the general population, of whom most patients $(57.6 \%)$ reported problems with emotional well-being. Van der Meer et al. [9] reported that $89 \%$ of patients had a significant impairment on at least one subscale of The European Organization for Research and Treatment of Cancer Quality of Life Questionnaire Core 30 (EORTC-QLQ-C30), and the most frequently affected aspect of HRQoL was physical functioning $(57 \%)$ [9]. Both studies indicate that the majority of patients already experience problems with HRQoL pre-SRS.

On the group level, our patients with BM reported statistically significant and clinically meaningful lower emotional well-being than the general population and adult cancer sample. The difference with other cancer patients may be explained by the emotional distress caused by a more recent diagnosis of a serious life-threatening disease and the upcoming treatment. In addition, our patients with BM probably were in a more advanced disease stage compared to the adult cancer sample and might therefore experience more emotional distress. Patients with BM reported significantly, and clinically meaningful, higher social well-being compared to the general population, which could be explained by the increase of support that patients receive just before the upcoming treatment. Habets et al. [8], evaluating group results in the same patient sample as van der Meer et al. [9], also found worse emotional functioning pre-SRS as compared to the general population, but their patients with BM also scored significantly worse on physical functioning and global health status/QoL, which was not found in the current study. Our patients with BM scored clinically meaningful better on physical well-being than the adult cancer sample, although this was not statistically significant.

A possible explanation for the differences between the results of the current study and those of the studies of Habets et al. [8] and van der Meer et al. [9], is the difference in questionnaires that were used to measure HRQoL. The EORTCQLQ-C30 used by Habets et al. [8] and van der Meer et al. [9] is known to be more focused on functional activities, while the FACT-Br used in the current study is more focused on functional symptoms [26, 27]. Patients with BM might experience or report more problems with functional activities, such as taking a long walk, than with functional symptoms, such as pain.

The before mentioned explanations for differences in HRQoL between the patients with BM and the adult cancer sample are primarily based on the moment at which the patients with BM completed the HRQoL questionnaire. The pretreatment HRQoL measurement is therefore very important when analyzing change in HRQoL over time, as changes over time in HRQoL could not only be due to treatmentrelated factors, but also due to factors that are already present at the pretreatment measurement. It is therefore advisable to interpret HRQoL results over time only after careful evaluation of HRQoL before treatment.

Overall, worse psychological factors, e.g. physical fatigue, depression, mental fatigue and anxiety, were predictive for lower pre-SRS HRQoL. Patients may experience additional anxiety or depression on the day of treatment, resulting in lower HRQoL. Pre-SRS, $42.4 \%$ and $32.6 \%$ of the patients scored above the cutoff for (at least) mild symptoms of anxiety and depression respectively. Clinicians and nursing staff should, if possible, pay extra attention to patients that experience these psychological complaints. A synchronous (as opposed to a metachronous) diagnosis of $\mathrm{BM}$ predicted better social well-being. This might be due to increased social support after a first-time diagnosis of a lifethreatening disease. Pre-SRS KPS did not predict HRQoL of patients with BM on any of the subscales, whereas in 
a previous study, using univariate analyses, pre-SRS KPS was associated with pre-SRS HRQoL [8]. In the univariate linear regression analyses of the current study KPS was also a significant positive predictor for 6 of the $8 \mathrm{HRQoL}$ scales, however KPS was no longer a significant predictor in the multiple regression analyses. Objectively tested cognitive performance did not predict any of the pretreatment aspects of HRQoL, whereas the absence of cognitive symptoms, as measured by self-report, was a significant predictor for HRQoL after SRS in the study of Skeie et al. [11]. This might be due to differences in measuring cognitive functioning; self-reported cognitive functioning might be more related to self-reported HRQoL than objectively tested cognitive functioning [28].

It should be noted that in this study a subset of patients with BM, eligible for GKRS and able and willing to complete an NPA, was included. Overall, patients with BM selected for GKRS have a relatively good clinical condition. In addition, a more resilient group of patients may have been included in this study compared to other HRQoL studies with less time-consuming and burdensome assessments (patients were also asked to complete several neuropsychological tests). Lastly, a heterogeneous study sample of patients with several types of primary cancers was included. Different primary tumors may have influenced aspects of HRQoL differently (e.g. due to their different symptoms or side effects). However, the study sample as a whole is representative for the group of patients with BM that is generally treated with GKRS in our center.

For patients with BM, HRQoL is a highly important factor in choosing among treatment options [5]. In future studies, HRQoL of patients with BM from different primary tumors may be analyzed separately. In addition, all aspects of HRQoL should be evaluated separately, as our findings show different outcomes for the different aspects of HRQoL and combining scores into a total score may potentially mask specific problems with aspects of HRQoL. Furthermore, the pre-SRS HRQoL state of patients should be analyzed before results on change over time in $\mathrm{HRQoL}$ are interpreted.

Since increasingly more patients with $\mathrm{BM}$ are being treated with SRS $[6,7]$, our findings are very relevant to a large group of patients with BM. There should be more awareness of the well-being of patients with BM before treatment; especially with respect to the low emotional wellbeing. Clinicians and nursing staff should be better informed on the pre-SRS HRQoL states of patients and the specific issues they are dealing with, and thereby better understand a patient's feelings and needs on the day of the treatment. Standard assessment of HRQoL in the clinical practice is helpful to identify patients' concerns [29], may improve communication between patients and clinicians, helps clinicians to provide patients with personalized information, and guide, if necessary, decisions on interventions for HRQoL problems after SRS. Interventions that have been found helpful for improving HRQoL include cognitive behavioral therapy or psychotherapy [30-32]. These interventions also aim at improving symptoms of anxiety and depression. Our findings indicated that it is important to address these psychological factors when aiming for improvement of HRQoL in patients with BM.

Acknowledgements This study was funded by ZonMw, the Netherlands organization for health research and development (Project No. 842003008).

\section{Compliance with ethical standards}

Conflict of interest All authors declare that they have no conflict of interest.

Open Access This article is distributed under the terms of the Creative Commons Attribution 4.0 International License (http://creativeco mmons.org/licenses/by/4.0/), which permits unrestricted use, distribution, and reproduction in any medium, provided you give appropriate credit to the original author(s) and the source, provide a link to the Creative Commons license, and indicate if changes were made.

\section{References}

1. Kaal EC, Niël CG, Vecht CJ (2005) Therapeutic management of brain metastasis. Lancet Neurol 4(5):289-298

2. Lassman AB, DeAngelis LM (2003) Brain metastases. Neurol Clin 21(1):1-23

3. Brown PD, Jaeckle K, Ballman KV, Farace E, Cerhan JH, Anderson SK et al (2016) Effect of radiosurgery alone vs radiosurgery with whole brain radiation therapy on cognitive function in patients with 1 to 3 brain metastases: a randomized clinical trial. JAMA 316(4):401-409

4. Chang EL, Wefel JS, Hess KR, Allen PK, Lang FF, Kornguth DG et al (2009) Neurocognition in patients with brain metastases treated with radiosurgery or radiosurgery plus wholebrain irradiation: a randomised controlled trial. Lancet Oncol 10(11):1037-1044

5. Zeng KL, Raman S, Sahgal A, Soliman H, Tsao M, Wendzicki $C$ et al (2017) Patient preference for stereotactic radiosurgery plus or minus whole brain radiotherapy for the treatment of brain metastases. Ann Palliat Med 6(2):S155-S160

6. Elaimy AL, Mackay AR, Lamoreaux WT, Fairbanks RK, Demakas JJ, Cooke BS et al (2011) Clinical outcomes of stereotactic radiosurgery in the treatment of patients with metastatic brain tumors. World Neurosurg 75(5):673-683

7. McTyre E, Scott J, Chinnaiyan P (2013) Whole brain radiotherapy for brain metastasis. Surg Neurol Int 4(Suppl 4):S236

8. Habets EJ, Dirven L, Wiggenraad RG, Verbeek-de Kanter A, Lycklama à Nijeholt GJ, Zwinkels H et al (2016) Neurocognitive functioning and health-related quality of life in patients treated with stereotactic radiotherapy for brain metastases: a prospective study. Neuro-oncology 18(3):435-444

9. van der Meer PB, Habets EJ, Wiggenraad RG, Verbeek-de Kanter A, à Nijeholt GJL, Zwinkels H et al (2018) Individual changes in neurocognitive functioning and health-related quality of life in patients with brain oligometastases treated with stereotactic radiotherapy. J Neurooncol 139(2):359-368 
10. Bragstad S, Flatebø M, Natvig GK, Eide GE, Skeie GO, Behbahani M et al (2017) Predictors of quality of life and survival following Gamma Knife surgery for lung cancer brain metastases: a prospective study. J Neurosurg 129(1):71-83

11. Skeie BS, Eide GE, Flatebø M, Heggdal JI, Larsen E, Bragstad S et al (2017) Quality of life is maintained using Gamma Knife radiosurgery: a prospective study of a brain metastases patient cohort. J Neurosurg 126(3):708-725

12. FACIT.org (2017). FACIT: providing a voice for patients worldwide. http://www.facit.org

13. Thavarajah N, Bedard G, Zhang L, Cella D, Beaumont JL, Tsao $M$ et al (2014) Psychometric validation of the functional assessment of cancer therapy - brain (FACT-Br) for assessing quality of life in patients with brain metastases. Support Care Cancer 22(4):1017-1028

14. Weitzner MA, Meyers CA, Gelke CK, Byrne KS, Levin VA, Cella DF (1995) The functional assessment of cancer therapy (FACT) scale. Development of a brain subscale and revalidation of the general version (FACT-G) in patients with primary brain tumors. Cancer 75(5):1151-1161

15. Cella DF, Tulsky DS, Gray G, Sarafian B, Linn E, Bonomi A et al (1993) The Functional Assessment of Cancer Therapy scale: development and validation of the general measure. $\mathrm{J}$ Clin Oncol 11(3):570-579

16. Brucker PS, Yost K, Cashy J, Webster K, Cella D (2005) General population and cancer patient norms for the Functional Assessment of Cancer Therapy-General (FACT-G). Eval Health Prof 28(2):192-211

17. Zigmond AS, Snaith RP (1983) The hospital anxiety and depression scale. Acta Psychiatr Scand 67(6):361-370

18. Smets E, Garssen B, Bonke BD, De Haes J (1995) The multidimensional fatigue inventory (MFI) psychometric qualities of an instrument to assess fatigue. J Psychosom Res 39(3):315-325

19. Benedict RH, Schretlen D, Groninger L, Brandt J (1998) Hopkins verbal learning test-revised: normative data and analysis of inter-form and test-retest reliability. Clin Neuropsychol 12(1):43-55

20. Tombaugh TN (2004) Trail making test A and B: normative data stratified by age and education. Arch Clin Neuropsychol 19(2):203-214

21. Bryden P, Roy E (2005) A new method of administering the Grooved Pegboard Test: performance as a function of handedness and sex. Brain Cogn 58(3):258-268

22. Chang EL, Wefel JS, Maor MH, Hassenbusch SJ III, Mahajan A, Lang FF et al (2007) A pilot study of neurocognitive function in patients with one to three new brain metastases initially treated with stereotactic radiosurgery alone. Neurosurgery 60(2):277-284
23. Rijnen SJ, Meskal I, Emons WH, Campman CA, van der Linden SD, Gehring K et al (2017) Evaluation of normative data of a widely used computerized neuropsychological battery: applicability and effects of sociodemographic variables in a Dutch sample. Assessment. https://doi.org/10.1177/1073191117727346

24. Cohen J (1988) Statistical power analysis for the behavioral sciences, 2nd edn. Lawrence Earlbaum Associates, Hillsdale, NJ

25. Benjamini Y, Hochberg Y (1995) Controlling the false discovery rate: a practical and powerful approach to multiple testing. J R Stat Soc B 57:289-300

26. Lin NU, Wefel JS, Lee EQ, Schiff D, van den Bent MJ, Soffietti R et al (2013) Challenges relating to solid tumour brain metastases in clinical trials, part 2: neurocognitive, neurological, and qualityof-life outcomes. A report from the RANO group. Lancet Oncol 14(10):e407-e416

27. Pham A, Lo SS, Sahgal A, Chang EL (2016) Neurocognition and quality-of-life in brain metastasis patients who have been irradiated focally or comprehensively. Expert Rev Qual Life Cancer Care 1(1):45-60

28. Gehring K, Taphoorn MJ, Sitskoorn MM, Aaronson NK (2015) Predictors of subjective versus objective cognitive functioning in patients with stable grades II and III glioma. Neuro-oncol Pract 2(1):20-31

29. Jacobsen PB, Davis K, Cella D (2002) Assessing quality of life in research and clinical practice. Oncology 16(9 Suppl 10):133-140

30. Jacobsen PB, Jim HS (2008) Psychosocial interventions for anxiety and depression in adult cancer patients: achievements and challenges. CA: Cancer J Clin 58(4):214-230

31. Osborn RL, Demoncada AC, Feuerstein M (2006) Psychosocial interventions for depression, anxiety, and quality of life in cancer survivors: meta-analyses. Int J Psychiatry Med 36(1):13-34

32. Breitbart W, Rosenfeld B, Pessin H, Applebaum A, Kulikowski J, Lichtenthal WG (2015) Meaning-centered group psychotherapy: an effective intervention for improving psychological well-being in patients with advanced cancer. J Clin Oncol 33(7):749

33. Spinhoven P, Ormel J, Sloekers P, Kempen G, Speckens A, Van Hemert A (1997) A validation study of the Hospital Anxiety and Depression Scale (HADS) in different groups of Dutch subjects. Psychol Med 27(2):363-370

34. Smets E, Garssen B, Cull A, De Haes J (1996) Application of the multidimensional fatigue inventory (MFI-20) in cancer patients receiving radiotherapy. $\mathrm{Br} \mathrm{J}$ Cancer 73(2):241

35. Verhage F (1964) Intelligentie en leeftijd: onderzoek bij Nederlanders van twaalf tot zevenenzeventig jaar. Van Gorcum, Assen

Publisher's Note Springer Nature remains neutral with regard to jurisdictional claims in published maps and institutional affiliations. 